\title{
Relationship between the anthropometric profile and physical fitness of surfers and their dynamic postural balance
}

\author{
Ronald Morales-Vargas' ${ }^{1}$ Pablo Valdes-Badilla², Eduardo Guzmán-Muñoz ${ }^{3}$ \\ ${ }^{1}$ Facultad de Salud. Universidad Santo Tomás. Chile. ${ }^{2}$ Departamento en ciencias de la actividad física. Facultad de Ciencias de la Educación. Universidad Católica del Maule. Talca. \\ Chile. ${ }^{3}$ Escuela de Kinesiología. Facultad de Salud. Universidad Santo Tomás. Chile.
}

doi: 10.18176/archmeddeporte.00033

Received: 01/09/2020

Accepted: 18/01/2021

Key words:

Postural balance. Anthropometric profile Physical aptitude. Surfing.

\section{Summary}

Introduction: Surfing is a discipline that has considerably increased the number of followers who practice this sport. Research has focused on describing the main variables associated with performance, but not the relationships that may exist between them.

Objective: To establish the relationship of dynamic postural balance with respect to the anthropometric profile and physical aptitude in surfers.

Material and method: This research is an observational and cross-sectional study of a descriptive-correlational type. The sample included 30 surfers ( 8 women and 22 men). The variables of the anthropometric profile studied were body mass, bipedal height, body mass index (BMI), sum of folds, body composition and somatotype. Furthermore, physical aptitude was assessed by indirect tests. The data of the anthropometric profile and physical aptitude were correlated with the results of the dynamic postural balance test (Y balance test).

Results: For the anterior direction of the Y balance test, the variables that were significant were gender, body weight, bipedal height, sum of folds, adipose mass and Sargent's jump height $\left(R^{2}=0.55\right)$. The posteromedial direction of the $Y$ balance test yielded a significant model that indicates that gender, sum of folds and adipose mass are the variables that jointly predict dynamic postural balance $\left(R^{2}=0.30\right)$. For the posterolateral direction, the model indicates that the BMI, sum of folds, adipose mass, mesomorphism, ectomorphism and performance in the sit and reach test are the variables that influence the performance of the $Y$ balance test $\left(R^{2}=0.55\right)$.

Conclusion: Predictive models were established to determine anthropometric and physical condition variables that would be decisive for the performance of a surfer's postural balance.

\section{Relación entre el perfil antropométrico y aptitud física con el equilibrio postural dinámico en surfistas}

\section{Resumen}

Introducción: El surf es una disciplina que ha aumentado considerablemente la cantidad de adeptos que practican este deporte. Las investigaciones se han orientado en describir las principales variables asociadas al rendimiento, pero no las relaciones que pueden existir entre ellas.

Objetivo: Establecer la relación del equilibrio postural dinámico con respecto al perfil antropométrico y aptitud física en surfistas.

Material y método: Esta investigación es un estudio de diseño observacional y transversal, de tipo descriptivo-correlacional. La muestra incluyo 30 surfistas (8 mujeres y 22 hombres). Las variables del perfil antropométrico estudiadas fueron: masa corporal, estatura bípeda, índice de masa corporal (IMC), suma de pliegues, composición corporal y somatotipo. Además, se evaluó la aptitud física mediante pruebas indirectas. Los datos del perfil antropométrico y aptitud física se correlacionaron con los resultados de la prueba de equilibrio postural dinámico ( $Y$ balance test).

Resultados: Para la dirección anterior del Y balance test, las variables que resultaron significativas fueron género, peso corporal, estatura bípeda, suma de pliegues, masa adiposa y altura del salto de Sargent $\left(R^{2}=0,55\right)$. La dirección posteromedial del $Y$ balance test arrojó un modelo significativo que indica que el género, suma de pliegues y masa adiposa son las variables que predicen conjuntamente el equilibrio postural dinámico $\left(R^{2}=0,30\right)$. Para la dirección posterolateral el modelo señala que el

Palabras clave: Equilibrio postural.

Perfil antropométrico. Aptitud física. Surf.
IMC, suma de pliegues, masa adiposa, mesomorfismo, ectomorfismo y rendimiento en la prueba sit and reach son las variables que influyen en rendimiento de la prueba $Y$ balance test $\left(R^{2}=0,55\right)$

Conclusión: Se establecieron modelos predictivos para determinar variables antropométricas y de la aptitud física que serían determinantes para el desempeño del equilibrio postural de un surfista. 


\section{Introduction}

Surfing as a discipline has grown exponentially over the last few years, to such an extent that it has been included in the upcoming Olympic games' ${ }^{1}$. Surfing is a dynamic sport performed in a highly unstable and changing environment, meaning that balance is an essential characteristic for these athletes ${ }^{2}$. In this respect, it has been surmised that postural balance is directly related to the improved performance and competition level of surfers².

Maintaining correct postural balance is a psychomotor challenge that includes a series of sensorimotor processes to reach optimal performance ${ }^{3}$. Postural balance or equilibrium is defined as a complex motor skill resulting from the interaction of a number of sensorimotor processes, directed at controlling the body in space ${ }^{3,4}$. This ranges from anticipatory and compensatory strategies up to the input of information from the visual, vestibular and somatosensory systems for integration into the central nervous system ${ }^{3,5}$

One of the most widely recognised methods for assessing dynamic postural balance is the Star Excursion Balance Test (SEBT) or its modified version, the Y Balance Test $t^{6}$. The SEBT protocol evaluates eight directions while the $Y$ balance test only evaluates three directions: anterior, posteromedial and posterolateral ${ }^{6}$. These directions have been shown to be the most sensitive in detecting postural balance alterations and the risk or injury? ${ }^{7}$ Despite the fact that surfing is a dynamic activity, investigations habitually report static postural balance evaluations through force plates $^{2,8}$. For this reason, suggestions were made to conduct dynamic evaluations in order to strengthen the scientific knowledge of this sport ${ }^{9}$.

For its part, the anthropometric profile may have an impact on the performance of athletes. Specifically, for surfers, it has been reported that the presence of less adipose tissue can predict greater athletic performance $^{10}$. It has also been reported that elite surfers present a balanced mesomorph somatotype, which reveals a characteristic body shape by type of athlete ${ }^{8,10}$. With regard to the physical capabilities necessary for good performance in surf, it has been reported that high cardiorespiratory fitness, high muscular strength and considerable anaerobic strength and power would be essential for optimal performance 9 . However, to date, there has been no investigation that relates the aforementioned variables for surfers with postural balance. Therefore, the aim of this study is to determine predictive models that could explain the postural balance of surfers based on anthropometric profile and physical fitness variables.

\section{Material and method}

This investigation is a cross-sectional, descriptive, correlational, observational study. Non-probability convenience sampling was used to select participants, who all signed an informed consent approved by the Ethics Committee of the Universidad Santo Tomás, Chile (61.19).

\section{Participants}

The sample included 30 surfers (22 men and 8 women) from the commune of Pichilemu (Chile), aged between 16 and 35 years and who had been surfing for at least 2 years. The following exclusion criteria were considered: a) Musculoskeletal injuries in the last 3 months; b) Surgery in the last 6 months on the upper or lower body; c) Vestibular disorders; $d$ ) Discomfort of any type when making the evaluations (for example: pain).

\section{Anthropometric profile}

The different evaluations made to determine the anthropometric profile were in accordance with the International Society for the Advancement of Kinanthropometry (ISAK)11. Standing stature was measured using a stadiometer (Seca ${ }^{\circledR}$ Hamburg, Germany, accurate to $0.1 \mathrm{~cm}$ ) and body weight with a digital scale (Seca ${ }^{\circledR}$ Hamburg, Germany, accurate to $0.1 \mathrm{~kg}$ ). These measurements gave the body mass index (BMI), dividing the body weight $(\mathrm{kg})$ by the square of the stature $\left(\mathrm{m}^{2}\right)$. An anthropometer (Rosscraft, Canada; accurate to $0.1 \mathrm{~mm}$ ) was used to measure the following breadths: biacromial; transverse chest, anteroposterior thorax, biliocristal, biepicondylar (humerus and Femur). 10 girths were measured with a tape measure (Sanny ${ }^{\circledR}$, Brazil; accurate to $0.1 \mathrm{~mm}$ ) which corresponded to: Head, arm relaxed, arm flexed and tensed, maximum forearm, mesosternum thorax, minimum waist, maximum hip, maximum thigh, medial muscle and maximum calf. Six skinfolds were measured with a calliper (Harpenden ${ }^{\oplus}$, England; accurate to $0.2 \mathrm{~mm}$ ) corresponding to triceps, subscapular, supraspinale, abdominal, medial thigh and ending with maximum calf). The above measurements served to calculate the pentacompartimental body composition, which establishes five components (epithelial mass, adipose mass, muscle mass, bone mass and residual mass) ${ }^{12}$. The somatotype (body shape and composition) was also determined using the equations established by Heath \& Carter (1990) based on three parameters which differ one from the other, either endomorph (a predominance of adiposity); mesomorph (high level of muscularity) and ectomorph (slender body) ${ }^{13}$.

\section{Physical fitness}

Prior to the evaluations, the participants were subjected to a general warm-up: joint mobility, 10 minute jog and sprinting with changes in speed. The participants subsequently took the physical fitness tests. Hamstrings - lower back flexibility was measured with the Sit and Reach Test ${ }^{14}$. Each participant sat on the floor with feet slightly apart and the soles of the feet placed flat against a measuring box, with the knees stretched out. From this position they were asked to reach forward as far as possible with their hands on the measuring box. Once in that position, the best distance was recorded $(\mathrm{cm})$.

The CORE abdominal strength was measured with the prone bridge test ${ }^{15}$. This test consisted in lying in a prone position, propped on the forearms, with the pelvis in a straight line with the rest of the body and 
with both feet hip-width apart. The surfer was asked to hold the position for as long as possible ${ }^{15}$.

The Sargent or vertical Jump test was used to measure the explosive power of the lower limbs in accordance with the protocol established by Harman, Rosenstein, Frykmam, Rosenstein \& Kraemer $(1991)^{16}$. The vertical jump test measures the difference between the height of the athlete with the hand stretched upwards (feet on the floor) and the height reached with that hand with a jump. 3 jumps were performed, taking the best measurement and with a 45 second rest between each attempt $^{17}$.

Agility was measured with the modified Illinois test ${ }^{18}$. The test starts with the participant lying in a prone position with arms at his/her side. At the command of a whistle, the participant must get up and run to the first cone in the circuit, then through a slalom course of four cones in the centre and back again, past the penultimate cone, and then complete the circuit $^{19}$. Each participant must complete the circuit in the shortest possible time.

The medicine ball throw test was used to determine the explosive force of the upper body ${ }^{20}$. A line was marked on the floor, where the athlete had to stand. Behind the line marking the starting point, with the feet at an equal distance and slightly apart, the ball was taken with both hands behind the head and the participant was asked to throw the medicine ball as far as possible ${ }^{20}$. The test used a medicine ball (3 kg for men; 2 kg for women), chalk and a tape measure (Sanny ${ }^{\circledR}$, Brazil; accurate to $0.1 \mathrm{~mm}$ ) to measure the distance $(\mathrm{cm})$ reached by the ball ${ }^{20}$.

Finally, to determine the maximum oxygen consumption $\left(\dot{\mathrm{VO}}_{2 \max }\right)$ the Shuttle Run ${ }^{21}$ test was used. Two lines were marked out, 20 metres apart, and participants were asked to run back and forth, making a change in direction at the rate indicated by a buzzer, with the frequency progressively increasing ${ }^{21}$. The test had a slow starting speed of $8 \mathrm{~km} / \mathrm{h}$, which was gradually increased up to a final speed of $18 \mathrm{~km} / \mathrm{h}^{21}$. During the test the subjects themselves are responsible for determining their own pace so that, when the signal is heard, the participant must be 1 to 2 metres from the end line. At each end, the line must be touched with the foot and the test ends when the subject either withdraws voluntarily from the test and/or when the participant can no longer keep up the pace imposed by the buzzer21,22. The $\dot{\mathrm{V}}_{2 \max }$ was estimated by the equations proposed by Leger et al. (1988)22:

For subjects under 18 years of age:

$\dot{\mathrm{V}} \mathrm{O}_{2 \max }=31.025+(3.238 \times F S R)-(3.248 \times$ Age $)+(0.1536 \times \mathrm{FSR} \times$ Age $)$

For subjects over 18 years of age:

$$
\dot{\mathrm{V}} \mathrm{O}_{2 \max }=(6 \times \mathrm{FSR})-27.4 \dot{\mathrm{V}} \mathrm{O}_{2 \max }=(6 \times F S R)-27.4
$$

$\dot{\mathrm{V}} \mathrm{O}_{2 \mathrm{max}}: \mathrm{mL} \cdot \mathrm{kg}^{-1} \cdot \mathrm{min}^{-1}$

FSR: Final speed reached in the last stage completed $\left(\mathrm{km} \cdot \mathrm{h}^{-1}\right)$ Age: Years.

\section{Dynamic postural balance}

Dynamic postural balance was evaluated using the Y Balance Test considering 3 directions: anterior, posteromedial and posterolateral. Each participant started the evaluation standing upright with their hands on their hips. When instructed to do so, the participant reached as far as possible with the lower limb. The dominant lower limb was evaluated which, for the purpose of this test, was the limb that supports the body weight6. Participants had three attempts in each direction, recording the best of the three ${ }^{6,23}$. The attempt was considered valid when the support foot did not leave the floor and the participant was able to return to the initial position without losing balance after doing the reach. A tape measure in centimetres (Sanny ${ }^{\circledast}$, Brazil, accurate to $0.1 \mathrm{~mm}$ ) was used to measure the distances achieved in all 3 directions. The final reach value of the lower limb was expressed as a percentage, normalizing the results to segment length with the following calculation:

(distance reached $(\mathrm{cm})$ )

\section{$\%$ Y Balance Test $=\underset{(\text { segment length }(\mathrm{cm})) \times 100}{ }$}

The segment length was measured considering the distance between the anterior superior iliac spine up to the medial malleolus of the ankle $e^{23}$.

\section{Statistical analysis}

The SPSS 23.0 (SPSS 23.0 for Windows, SPSS Inc., IL, USA) software was used for the data analysis. The mean and standard deviation were calculated to describe the characteristics of the sample: anthropometric profile (anthropometric measures, body composition and somatotype), physical fitness and dynamic postural balance. The Shapiro-Wilk was applied to assess the distribution of the data and, subsequently, a multiple linear regression model was applied (confidence interval of 95\%) to determine the impact of the anthropometric profile and physical fitness on the 3 directions of the dynamic balance test. The collinearity of the variables present in the analysis was verified using values with a tolerance of less than 0.10 and, for values above 10.0, a variance inflation factor (VIF) to confirm the non-existence of multicollinearity. The level of significance for all the statistical tests was $<0.05$.

\section{Results}

The 30 surfers evaluated ( 8 women and 22 men) had a mean age of 26.0 years, body weight of $70.5 \mathrm{~kg}$, standing stature of 169.4 and BMI of $24.4 \mathrm{~kg} / \mathrm{m}^{2}$. The sample, based on the body composition, obtained 23.5\% adipose mass and $47.7 \%$ muscle mass. The somatotype classification places the participants as Meso-endomorphs (3.1 - 5.7 - 1.7). Table 1 shows the anthropometric characteristics of the surfers assessed, distributed according to gender. The descriptive results of the physical fitness and postural balance of the surfers evaluated are provided in Tables 2 and 3 respectively.

\section{Multiple linear regression analysis}

The significant variables in the models are shown in Table 3. For the anterior direction of the $Y$ balance test, the significant variables were 
Table 1. Anthropometric measurements, body composition and somatotype of the surfers (mean and standard deviation).

\begin{tabular}{lcc}
\hline & Men (n=8) & Women $(\mathbf{n = 2 2 )}$ \\
\hline Age (years) & $25.6(3.5)$ & $26.1(5.3)$ \\
Body weight (kg) & $59.4(6.6)$ & $74.5(11.9)$ \\
Standing Stature (m) & $162.2(7.7)$ & $171.9(7.5)$ \\
BMI (kg/m $\left.{ }^{2}\right)$ & $22.5(1.1)$ & $25.2(3.4)$ \\
Skinfold sum (mm) & $78.1(21.5)$ & $67.3(34.7)$ \\
Adipose mass (\%) & $27.6(4.1)$ & $22.0(4.1)$ \\
Muscle mass (\%) & $44.4(3.5)$ & $48.9(3.2)$ \\
Residual mass (\%) & $10.9(0.4)$ & $12.4(0.9)$ \\
Bone mass (\%) & $11.4(1.1)$ & $11.8(1.1)$ \\
Epithelial mass (\%) & $5.5(0.4)$ & $4.9(0.5)$ \\
Endomorph & $3.5(1.2)$ & $2.9(1.7)$ \\
Mesomorph & $4.9(1.1)$ & $6.0(1.3)$ \\
Ectomorph & $1.9(0.6)$ & $1.7(1.1)$ \\
\hline
\end{tabular}

BMl: body mass index.

Table 2 Results of the physical fitness and dynamic balance tests of surfers (mean and standard deviation).

\begin{tabular}{lcc}
\hline & Men (n=8) & Women $(\mathbf{n = 2 2})$ \\
\hline Physical fitness & & \\
Sit and reach (cm) & $13.9(2.9)$ & $4.9(8.5)$ \\
Prone bridge (s) & $147.1(36.9)$ & $163.4(80.1)$ \\
Sargent Jump (m) & $37.9(4.8)$ & $45.8(5.3)$ \\
Illinois agility test (s) & $18.2(0.8)$ & $17.1(0.7)$ \\
Ball throw (m) & $367.5(45.7)$ & $525.1(73.9)$ \\
Shuttle run (ml*kg ${ }^{*}$ min) & $38.9(4.1)$ & $44.9(5.3)$ \\
Y Balance Test Directions & & \\
Anterior (\%) & $72.0(8.7)$ & $67.4(5.5)$ \\
Posteromedial (\%) & $124.1(12.7)$ & $118.2(6.9)$ \\
Posterolateral (\%) & $114.7(9.8)$ & $111.3(9.3)$ \\
\hline
\end{tabular}

gender, body weight, standing stature, skinfold sum, adipose mass and Sargent jump height. This model has an explanation level of 55.1\% and shows that women surfers, with less body weight, smaller in stature, thinner skinfolds, lower adipose mass and who achieve a greater height in the Sargent test, have a better dynamic postural balance.

The posteromedial direction of the Y Balance Test yielded a significant model that indicates that gender, skinfold sum and adipose mass are variables that together predict the dynamic postural balance. The model obtained has an explanation level of $30.2 \%$ and indicates that women surfers with thinner skinfolds and less adipose mass have a better dynamic postural balance.

For the posterolateral direction the model indicates that the BMI, skinfold sum, adipose mass, mesomorphism, ectomorphism and performance in the sit and reach test are the variables to influence performance of the $Y$ Balance Test. Surfers with a lower BMI, thinner skinfolds, lower adipose mass, greater tendency to mesomorphism, lesser tendency to ectomorphism and greater performance in the Sit and Reach test, have a greater dynamic postural balance. The explanation level of the model is $55.2 \%$.

\section{Discussion}

The principal result of this investigation indicates that the anthropometric profile and physical fitness explain the postural balance performance of surfers. Furthermore, the study also showed that gender is also a variable that has an influence on postural balance, where women offer a better performance. Specifically, it was observed that anthropometric variables relating to adiposity (BMI, sum of skinfolds and adipose mass), lower body explosive power and hamstrings - lower back flexibility, can together predict the performance in the $Y$ Balance Test. To the best of

Table 3 Significant multiple linear regression models obtained for dynamic postural balance

\begin{tabular}{|c|c|c|c|c|c|}
\hline Variables & $\mathbf{R}^{2}$ & B Coefficient & $p$ & \multicolumn{2}{|c|}{$\mathrm{Cl} 95 \%$} \\
\hline Anterior direction (\%) & 0.551 & & & & \\
\hline Gendera & & -18.66 & 0.003 & -30.16 & -7.16 \\
\hline Body weight & & -2.14 & 0.001 & -3.22 & -1.06 \\
\hline Stature & & -2.12 & 0.001 & -3.27 & -0.97 \\
\hline Skinfold sum & & -1.29 & 0.001 & -1.92 & -0.66 \\
\hline Adipose mass & & -7.51 & 0.001 & -11.24 & -3.78 \\
\hline Sargent Jump & & 0.52 & 0.039 & 0.02 & 1.02 \\
\hline Posteromedial direction (\%) & 0.302 & & & & \\
\hline Gendera & & -15.74 & 0.010 & -26.14 & -5.33 \\
\hline Skinfold sum & & -0.17 & 0.041 & -0.41 & -0.06 \\
\hline Adipose mass & & -2.11 & 0.021 & -3.95 & -0.2 \\
\hline Posterolateral direction (\%) & 0.552 & & & & \\
\hline $\mathrm{BMI}$ & & -5.84 & 0.011 & -10.21 & -1.47 \\
\hline Skinfold sum & & -1.30 & 0.006 & -2.19 & -0.40 \\
\hline Adipose mass & & -7.01 & 0.005 & -11.68 & -2.35 \\
\hline Mesomorph & & 9.60 & 0.012 & 2.28 & 16.93 \\
\hline Ectomorph & & -9.48 & 0.024 & -17.58 & -1.38 \\
\hline Sit and reach & & 0.49 & 0.016 & 0.10 & 0.89 \\
\hline
\end{tabular}

BMI: body mass index; C195\%: 95\% confidence interval; ${ }^{\circ}$ Gender: female=0; male $=1$ 
knowledge, this is the first study to consider predictive dynamic postural balance models based on anthropometric and physical fitness variables.

A prior study demonstrated that surfers had a positive correlation between competition level and a mesomorph body type, while a negative correlation was reported between an endomorph body type, skinfold sum and fat percentage ${ }^{10}$. This could be related to the findings of our study, whereby those surfers who demonstrated greater ability in the Y Balance Test were observed to be more mesomorph and less endomorph. Another investigation reported that surfers with a higher competitive rank had a greater vertical jump ability ${ }^{24}$, which is similar to our findings in which those surfers who had a greater postural balance in the anterior direction of the Y Balance Test, achieved a better performance in the vertical jump test evaluated.

For the general population, it has been reported that individuals with greater adiposity are associated with a lower dynamic postural balance performance ${ }^{25}$. The findings observed in this study indicate that the anthropometric variables for adiposity have a direct impact on the lower dynamic postural balance of surfers. It has been suggested that fat tissue accumulation around and in the muscle could alter the normal motor response mechanisms due to physiological and neuromuscular change ${ }^{26}$. The accumulation of fat would increase the expression of proinflammatory cytokines in the muscle, which could reduce the electrochemical balance and neural conductance in the muscle fibre ${ }^{27}$. These changes in the muscle fibre would create an alteration in the action potential conduction velocity, giving slower muscle responses ${ }^{26,27}$. Likewise, it has been seen that individuals with higher body fat show alterations in the muscle activation patterns for anticipatory and compensatory responses alike ${ }^{28}$. This would affect the muscle response due to lower neuromuscular efficiency in motor unit recruitment.

In this study, the physical fitness tests were also a determining factor in the dynamic postural balance of the surfers, where the flexibility and explosive force of the lower limbs were predictor variables of the performance achieved in the $Y$ Balance Test. It has been contended that optimum flexibility helps achieve an adequate dynamic postural balance ${ }^{29}$. A reduction in flexibility would provoke changes in musculotendinous stiffness and in the stretch reflex sensitivity ${ }^{29}$. It has been seen that constant flexibility stimulation, primarily in the hip, knee and ankle, would activate the mechanoreceptors located in the viscoelastic tissue of the joints, generating a desensitization process, which would contribute to the better controlof the stretch reflex according to the different postural oscillations ${ }^{29}$. For its part, the explosive force of the lower body was considered to be key to the execution of the principal and progressive manoeuvres in surfing competitions ${ }^{24}$. The lower limbs are ultimately responsible for mounting the surfboard and for performing the manoeuvres through foot contact with the board ${ }^{24}$. A number of studies have demonstrated that elite surfers have a greater explosive force in their lower body compared to surfers of a lower competition level ${ }^{30,31}$. The foregoing could explain the better performance of surfers with a greater flexibility and explosive force in the lower body.
This study revealed that women surfers have a greater dynamic postural balance than men in all directions of the Y Balance Test. Prior studies show that women athletes have a greater postural balance compared to men in the SEBT, primarily in the anterior direction ${ }^{32}$. Moreover, it has been suggested that women have greater flexibility than men, which could have an influence on the dynamic postural balance results, due to the fact that they may exhibit less joint stiffness ${ }^{29}$. The lack of flexibility would lead to an alteration in the muscle activation patterns ${ }^{33}$, affecting the motor performance in general. It has been established that the ideal reach pattern in the anterior direction of the Y Balance Test involves the maximum flexion of the knee and hip $^{34}$, therefore the flexibility of the lower body plays a key part in achieiving optimal performance. It has been shown that the electromyographic activity of the vastus medialis oblique muscle and the vastus lateralis muscle for the limb evaluated in the $Y$ Balance Test is greater in women in the anterior direction compared to the other directions, which is in keeping with the greater flexion of the knee and hip achieved by women in this test ${ }^{34}$. Women may possibly make more efficient use of the musculature, permitting better performance in the sagittal plane.

The study limitations include the small sample size, the nonprobability selection of participants, the broad age range of the subjects and the lower percentage of women than men assessed in the investigation. This could limit the external validity of the study. Future investigations could consider evaluations on the shortening of muscles and joint ranges, as this could complement our results. Likewise, further investigations could include evaluations of the upper body strength given that surfers constantly use this part of the body when paddling.

\section{Conclusions}

In conclusion, this study has served to determine that certain variables relating to the anthropometric profile and physical fitness exert an influence on the dynamic postural balance performance of surfers. Furthermore, gender, skinfold sum, adipose mass, mesomorph body type, ectomorph body type, explosive power of the lower body and hamstring-lower back flexibility are all dynamic balance predicting factors in the sample studied. This initial data suggests that it could be possible to predict the dynamic balance of surfers based on physical fitness and anthropometric parameters, primarily related to adiposity.

\section{Conflict of interests}

The authors have no conflict of interest at all.

\section{Bibliography}

1. Redd MJ, Fukuda DH, Beyer KS, Oliviera LP. No observable relative age effects in professional surfers: a constraints-based evaluation. Int J Exerc Sci. 2018;1 1:355-63.

2. Paillard T, Margnes E, Portet M, Breucq A. Postural ability reflects the athletic skill leve of surfers. Eur J Appl Physiol. 2011;111:1619-23.

3. Peterka RJ, Loughlin PJ. Dynamic regulation of sensorimotor integration in human postural control. J Neurophysiol. 2004;91:410-23. 
4. HorakFB. Postural orientation and equilibrium: what do we need to know about neural control of balance to prevent falls?. Age Ageing. 2006;35:7-11.

5. Maurer C, Mergner T, Peterka RJ. Multisensory control of human upright stance. Exp Brain Res. 2006;171:231-50.

6. Gribble PA, Hertel J, Plisky P. Using the Star Excursion Balance Test to Assess Dynamic Postural-Control Deficits and Outcomes in Lower Extremity Injury: A Literature and Systematic Review. J Ath/ Train. 2012;47:339-57.

7. Hertel J, Braham RA, Hale SA, Olmsted-Kramer LC. Simplifying the star excursion balance test: Analyses of subjects with and without chronic ankle instability. J Orthop Sports Phys Ther. 2006;36:131-7.

8. Valdes V MI, Guzman-Venegas R. Description of somatotype and physical qualities of experienced chilean men surfers. Int J Morphol. 2016;34:23-8.

9. Farley ORL, Abbiss CR, Sheppard JM. Performance analysis of surfing: a review. J Strength Cond Res. 2017;31:260-71.

10. Barlow MJ, Findlay M, Gresty K, Cooke C. Anthropometric variables and their relationship to performance and ability in male surfers. Eur J Sport Sci. 2014;14:S171-S7.

11. Marfell-Jones MJ, Stewart A, de Ridder J. International standards for anthropometric assessment. 2012.

12. Kerr DA. An anthropometric method for fractionation of skin, adipose, bone, muscle and residual tissue masses in males and females age 6 to 77 years. Theses (School of Kinesiology), Simon Fraser University; 1988.

13. Heath BH, Carter J. E. Somatotyping development and applications. New York, Cambridge University Press. 1990

14. Ayala F, de Baranda PS, de Ste Croix M, Santonja F. Fiabilidad y validez de las pruebas sit-and-reach: revisión sistemática. Rev Andaluza Med Deporte. 2012;5:57-66.

15. De Blaiser C, De Ridder R, Willems T, Danneels L, Vanden Bossche L, Palmans T, et al. Evaluating abdominal core muscle fatigue: Assessment of the validity and reliability of the prone bridging test. Scand J Med Sci Sports. 2018;28:391-9.

16. Harman EA, Rosenstein MT, Frykman PN, Rosenstein RM, Kraemer WJ. Estimation of human power output from vertical jump. J Strength Cond Res. 1991;5:116-20.

17. da Costa Mendes de Salles PG, do Amaral Vasconcellos FV, da Costa Mendes de Salles GF, Fonseca RT, Martin Dantas EH. Validity and Reproducibility of the Sargent Jump Test in the Assessment of Explosive Strength in Soccer Players. J Hum Kinet. 2012;33:115-21.

18. Vescovi JD, McGuigan MR. Relationships between sprinting, agility, and jump ability in female athletes. J Sports Sci. 2008;26:97-107.

19. Raya MA, Gailey RS, Gaunaurd IA, Jayne DM, Campbell SM, Gagne E, et al. Comparison of three agility tests with male servicemembers: Edgren Side Step Test, T-Test, and Illinois Agility Test. J Rehabil Res Dev. 2013;50:951-60.
20. Martínez E Aplicación de la prueba de lanzamiento de balón medicinal, abdominales superiores y salto horizontal a pies juntos: resultados y análisis estadístico en educación secundaria. Rev Int Med Cienc Act Fís Deporte. 2003;3:223-41

21. García GC, Secchi JD. Test course navette de 20 metros con etapas de un minuto. Una idea original que perdura hace 30 años. Apunts Med 'Esport. 2014;49:93-103.

22. Torres-Luque G, Carpio E, Sánchez AL, Sánchez MLZ. Niveles de condición física de escolares de educación primaria en relación a su nivel de actividad física y al género. Retos. 2014:17-22

23. Gribble PA, Kelly SE, Refshauge KM, Hiller CE. Interrater reliability of the star excursion balance test. J Ath/ Train. 2013;48:621-6

24. Fernandez-Gamboa I, Yanci J, Granados C, Camara J. Comparison of anthropometry and lower limb power qualities according to different levels and ranking position of competitive surfers. J Strength Cond Res. 2017;31:2231-7.

25. Guzman-MuñozE, Valdes-Badilla P, Mendez-Rebolledo G, Concha-Cisternas Y, CastilloRetamal M. Relación entre el perfil antropométrico y el balance postural estático y dinámico en niños de 6 a 9 años. Nutr Hosp. 2019;36:32-8.

26. Pajoutan M, Sangachin MG, Cavuoto LA. Central and peripheral fatigue development in the shoulder muscle with obesity during an isometric endurance task. BMC MusCuloskelet Disord. 2017:18:314.

27. Addison O, Drummond MJ, Lastayo PC, Dibble LE, Wende AR, McClain DA, et al. Intramuscular fat and inflammation differ in older adults: The impact of frailty and inactivity. J Nutr Health Aging. 2014;18:532-8.

28. Mendez-Rebolledo G, Guzman-Munoz E, Ramirez-Campillo R, Valdes-Badilla P, CruzMontecinos C, Morales-Verdugo J, et al. Influence of adiposity and fatigue on the scapular muscle recruitment order. Peerj. 2019;7:18.

29. Nelson AG, Kokkonen J, Arnall DA, Li L. Acute stretching increases postural stability in nonbalance trained individuals. J Strength Cond Res. 2012;26:3095-100.

30. Sheppard JM, McNamara P, Osborne M, Andrews M, Borges TO, Walshe P, et al. Association between anthropometry and upper-body strength qualities with sprint paddling performance in competitive wave surfers. J Strength Cond Res. 2012;26:3345-8.

31. Tran TT, Lundgren L, Secomb J, Farley ORL, Haff GG, Seitz LB, et al. Comparison of Physical Capacities Between Nonselected and Selected Elite Male Competitive Surfers for the National Junior Team. Int J Sports Physiol. 2015;10:178-82

32. Stiffler MR, Sanfilippo JL, Brooks MA, Heiderscheit BC. Star Excursion Balance Test Performance Varies by Sport in Healthy Division I Collegiate Athletes. J Orthop Sports Phys. 2015:45:772-80

33. Guzmán-Muñoz E, Mendez-Rebolledo G, Gatica-Rojas V. Retraso de la latencia de activación de los músculos de cadera y rodilla en individuos con acortamiento de la banda iliotibial. Fisioterapia. 2017;39:116-21

34. Gribble PA, Robinson RH, Hertel J, Denegar CR. The Effects of Gender and Fatigue on Dynamic Postural Control. J Sport Rehab. 2009;18:240-57. 